\title{
Effects of Cattle Stocking Rates on Nematode Communities in South Florida
}

\author{
Robert McSorley ${ }^{1}$ and George W. Tanner ${ }^{2}$ \\ Authors are ${ }^{1}$ Professor, Entomology and Nematology Department, University of Florida, Gainesville, FL 32611; \\ and ${ }^{2}$ Professor, Wildlife Ecology and Conservation Department, University of Florida, Gainesville, FL 32611.
}

\begin{abstract}
Ranch management practices aimed at cattle and pasture vegetation have the potential to impact other animals as well, including nontarget organisms. Soil-inhabiting nematodes are often used as bioindicators of nontarget effects because of their widespread occurrence and their diverse trophic habits and lifestyles. The effect of cattle stocking rates on nematode communities present in the soil was examined at the MacArthur Agro-Ecology Research Center in south-central Florida. Nematode abundance and richness (genera per sample) were not affected $(P>0.10)$ by cattle grazing in 2 different pasture types (tame grass and native) over three seasons. In general, populations of most nematodes showed strong seasonal responses, varying in numbers from year to year, possibly related to soil moisture levels. In comparison, the cattle stocking rates typically used in south-central Florida had little effect on soil nematodes, which were abundant nontarget organisms in this system.
\end{abstract}

\section{Resumen}

Las prácticas de manejo de pastizales dirigidos al ganado y la vegetación también tienen el potencial de impactar otros animales, incluyendo organismos que no son el blanco de interés. Por su amplia dispersión y sus diversos hábitats tróficos y estilos de vida, los nemátodos que habitan el suelo a menudo son usados como bioindicadores de efectos no deseados. Se examinó el efecto de las cargas animal del ganado sobre las comunidades de nemátodos presentes en el suelo en la Estación Experimental AgroEcológica McArthur localizada en el centro-sur de Florida. La abundancia y riqueza (géneros por muestra) de nemátodos no fueron afectados $(P>0.10)$ por el apacentamiento de ganado en 2 tipos diferentes de pradera (introducida y nativa) durante tres estaciones. En general, la población de la mayoría de los nemátodos mostraron fuertes respuestas estaciónales variando en número de año a año, posiblemente en función de los niveles de humedad del suelo. Las cargas animal típicamente usadas en la región centro-sur de Florida tienen poco efecto en los nemátodos del suelo, los cuales fueron abundantes en el sistema.

Key Words: bioindicators, grazing, nontarget organisms, pastures, ranch management, richness, trophic structure

\section{INTRODUCTION}

Ecosystems contain diverse communities of living organisms, from well-known vertebrates to relatively obscure microscopic forms (Begon et al. 1990; Stiling 2002). Any management practice applied for a specific purpose to an ecosystem may unintentionally disrupt some of these nontarget organisms that invariably occur within the system. For example, ruminant grazing impacts both native herbaceous plants and smaller herbivores in grassland ecosystems (Bolen and Robinson 1999). However, aboveground grazing impacts belowground processes as well (Bardgett and Wardle 2003), affecting microscopic soil organisms involved in decomposition processes (Coleman and Crossley 1996). Nematodes are a particularly diverse and abundant group of invertebrates that respond to a variety of disturbances to soil ecosystems including input of organic matter (Ferris et al. 2001; Wang

Research was supported in part by USDA/NRECGP Agricultural Systems Program Grant 97-35108-5125. This article is contribution 98 of the MacArthur Agro-ecology Research Center.

Correspondence: Robert McSorley, Dept of Entomology and Nematology, University of Florida, P0 Box 110620, Gainesville, FL 32611-0620. Email: mcsorley@ufl.edu

Manuscript received 12 July 2005; manuscript accepted 15 October 2006. et al. 2004c), tillage (Fiscus and Neher 2002), cover crops (Ferris et al. 2004; Wang et al. 2004a), and input of fertilizer nutrients and other chemicals (Ferris et al. 2004; Fiscus and Neher 2002; Wang et al. 2004b). Aboveground grazing impacts on nematodes are variable (Mulder et al. 2003), but linked to the quantity and quality of resultant organic matter and microbial biomass, with more impact on bacterivores expected in fertile systems and more impact on fungivores in infertile systems (Bardgett and Wardle 2003; Wardle et al. 2004).

This article is the third in a series of 4 articles from an integrated project addressing the influence of stocking density on the ecological, production, and economic aspects of ranch management systems in the subtropical rangelands of south central Florida. The current study seeks to determine the impact of aboveground grazing of grass by different cattle densities on belowground nematode communities in these pasture-based ecosystems. Nematodes possess many characteristics of good bioindicators (Anderson 1999), their responses to a variety of environmental factors are relatively well documented (McSorley 1997a; Bongers and Bongers 1998 ), and the group includes genera with a variety of different feeding habits (Bongers and Bongers 1998). Our null hypothesis was that grazing by 
Table 1. Effect of stocking rate on nematode numbers per $100 \mathrm{~cm}^{3}$ soil over time, in summer/tame pastures at end of summer grazing cycle.

\begin{tabular}{|c|c|c|c|c|c|c|}
\hline \multirow{2}{*}{$\begin{array}{l}\text { Cow-calf } \\
\text { pairs per } \\
\text { pasture }\end{array}$} & \multicolumn{3}{|c|}{ Numbers per $100 \mathrm{~cm}^{3}$ soil } & \multicolumn{3}{|c|}{ ANOVA $F$ values } \\
\hline & $\begin{array}{c}23 \text { November } \\
1999\end{array}$ & $\begin{array}{c}30 \text { October } \\
2001\end{array}$ & $\begin{array}{c}19 \text { November } \\
2002\end{array}$ & $\begin{array}{c}\text { Stocking } \\
\text { density }\end{array}$ & Time & $\begin{array}{l}\text { Density } \\
\times \text { time }\end{array}$ \\
\hline \multicolumn{7}{|c|}{ Bacterivores } \\
\hline 0 & 795 & 246 & 282 & 1.05 & $8.17^{1}$ & 2.63 \\
\hline 15 & 416 & 436 & 136 & & & \\
\hline 20 & 564 & 341 & 200 & & & \\
\hline 35 & 458 & 866 & 185 & & & \\
\hline \multicolumn{7}{|l|}{ Fungivores } \\
\hline 0 & 504 & 132 & 180 & 0.41 & $18.34^{2}$ & 0.41 \\
\hline 15 & 434 & 126 & 88 & & & \\
\hline 20 & 571 & 110 & 142 & & & \\
\hline 35 & 360 & 160 & 125 & & & \\
\hline \multicolumn{7}{|l|}{ Herbivores } \\
\hline 0 & 684 & 533 & 628 & 0.20 & 2.91 & 1.00 \\
\hline 15 & 506 & 681 & 290 & & & \\
\hline 20 & 465 & 754 & 288 & & & \\
\hline 35 & 386 & 1356 & 169 & & & \\
\hline \multicolumn{7}{|l|}{ Omnivores } \\
\hline 0 & 3.0 & 4.0 & 0 & 0.86 & 0.85 & 1.24 \\
\hline 15 & 3.5 & 1.0 & 0.5 & & & \\
\hline 20 & 4.5 & 0.5 & 7.0 & & & \\
\hline 35 & 3.0 & 1.5 & 0.5 & & & \\
\hline \multicolumn{7}{|l|}{ Predators } \\
\hline 0 & 7.0 & 3.5 & 2.5 & 1.31 & 4.22 & 1.04 \\
\hline 15 & 2.5 & 0.5 & 0.5 & & & \\
\hline 20 & 10.5 & 0.5 & 1.0 & & & \\
\hline 35 & 2.5 & 0 & 3.0 & & & \\
\hline \multicolumn{7}{|c|}{ Total nematodes } \\
\hline 0 & 2007 & 928 & 1104 & 0.35 & $4.47^{1}$ & 1.38 \\
\hline 15 & 1369 & 1255 & 520 & & & \\
\hline 20 & 1630 & 1218 & 648 & & & \\
\hline 35 & 1218 & 2394 & 488 & & & \\
\hline
\end{tabular}

${ }^{1} F$ values from analysis of variance (ANOVA) significant at $P<0.05$.

${ }^{2} F$ values from analysis of variance (ANOVA) significant at $P<0.01$.

different cattle densities would have no effect on nematode abundance or richness.

\section{MATERIALS AND METHODS}

Sixteen experimental pastures were established at 2 locations at the MacArthur Agro-Ecology Research Center (MAERC) at Buck Island Ranch in Highlands County, Florida (lat $27^{\circ} 9^{\prime} \mathrm{N}$, long $81^{\circ} 11^{\prime} \mathrm{W}$ ) (see Swain et al. 2007 for details). The improved pasture site intended for cattle grazing during the summer months consisted largely of bahiagrass (Paspalum notatum Fluegge), and was subdivided into 8 20-ha experimental pastures. The winter pasture location, which was somewhat wetter and contained more native grasses mixed with bahiagrass, was similarly subdivided into 8 32-ha pastures. In 1998 a grazing study was initiated, consisting of 4 different cattle stocking densities: $0,15,20$, or 35 cow-calf pairs per pasture. These densities were established following a workshop with local ranchers that have had decades of experience grazing similar pasture types. The objective was to have no grazing and light, normal, and heavy stocking densities. Each stocking rate was replicated twice for each pasture type (winter vs. summer pastures). Cattle grazed the improved summer pastures from May to October and the seminative winter pastures from November to April each year. Forage production is typically higher in the summer than in winter; therefore larger pastures were used in the winter to provide similar amounts of forage in both seasons. Prior to the initiation of these grazing treatments, cattle grazed the 2 pasture types at an average stocking density of approximately 1 hectare per cow-calf pair and 1.6 hectare per cow-calf pair on the summer and winter pastures, respectively. The differential grazing treatments were first established when cattle were moved to the winter pastures in October 1998 (summer pastures remained ungrazed from October 1998 to April 1999).

Soil samples for nematode analysis were collected from grazed pastures at the end of each grazing cycle. Sampling was repeated over 3 years (6 grazing cycles). No nematode samples were collected in 2000 because of the unusually dry soil conditions in that year. Each sample consisted of 6 soil cores (2.5-cm diameter $\times 20-\mathrm{cm}$ deep) collected systematically from a $10 \times 10 \mathrm{~m}$ area within the pasture. This $10 \times 10 \mathrm{~m}$ area was consistently located about $50 \mathrm{~m}$ from the spot where shelter and water were provided to the cattle. The six soil cores per sample were mixed well, and a $100-\mathrm{cm}^{3}$ subsample was removed for extraction of nematodes with the use of a standard sieving and centrifugation procedure (Jenkins 1964). Extracted nematodes were identified to genus in most cases, and counted under an inverted microscope by the same observer to reduce variability. Based on literature (Yeates et al. 1993; McSorley and Frederick 1999), nematodes were assigned to 5 trophic groups: bacterivores, fungivores, herbivores, omnivores, or predators, and the total numbers of nematodes in each trophic group were determined. Because each pasture was sampled seasonally during 3 years, a repeated-measures analysis of variance (ANOVA) was performed with the use of the PROC MIXED procedure of SAS (Statistical Analysis System, Cary, NC) to examine the effect of stocking density on nematode population level. On two sampling dates, soil moisture content was determined by removing $4 \mathrm{~g}$ of fresh soil from each sample collected and drying overnight to constant weight in an oven at $70^{\circ} \mathrm{C}$.

\section{RESULTS}

Over 25,000 nematodes were collected and identified during the course of this study, with herbivores comprising $45.6 \%$ of the total from summer pastures (Table 1 ) and $42.6 \%$ in winter pastures (Table 2). Bacterivores $(33.3 \%$ of total in summer pastures, $16.0 \%$ in winter pastures) and fungivores $(19.8 \%$ in summer pastures, $40.1 \%$ in winter pastures) were also abundant in all samples (Tables 1 and 2). None of the nematode trophic groups were significantly affected $(\mathrm{P}>0.10)$ by cattle density following grazing of the summer pastures (Table 1). Across all 3 
Table 2. Effect of stocking rate on nematode numbers per $100 \mathrm{~cm}^{3}$ soil over time, in winter/native pastures at end of winter grazing cycle.

\begin{tabular}{|c|c|c|c|c|c|c|}
\hline \multirow{2}{*}{$\begin{array}{c}\text { Cow-calf } \\
\text { pairs per } \\
\text { pasture }\end{array}$} & \multicolumn{3}{|c|}{ Numbers per $100 \mathrm{~cm}^{3}$ soil } & \multicolumn{3}{|c|}{ ANOVA $F$ values } \\
\hline & $\begin{array}{c}15 \text { April } \\
1999\end{array}$ & $\begin{array}{c}6 \text { June } \\
2002 \\
\end{array}$ & $\begin{array}{c}3 \text { June } \\
2003\end{array}$ & $\begin{array}{c}\text { Stocking } \\
\text { density }\end{array}$ & Time & $\begin{array}{l}\text { Density } \\
\times \text { time } \\
\end{array}$ \\
\hline \multicolumn{7}{|c|}{ Bacterivores } \\
\hline 0 & 84 & 94 & 135 & 1.91 & $10.98^{2}$ & $4.17^{1}$ \\
\hline 15 & 105 & 87 & 435 & & & \\
\hline 20 & 152 & 67 & 158 & & & \\
\hline 35 & 199 & 80 & 179 & & & \\
\hline \multicolumn{7}{|c|}{ Fungivores } \\
\hline 0 & 594 & 313 & 172 & 1.88 & 1.09 & 1.54 \\
\hline 15 & 506 & 173 & 1504 & & & \\
\hline 20 & 272 & 146 & 112 & & & \\
\hline 35 & 432 & 96 & 138 & & & \\
\hline \multicolumn{7}{|c|}{ Herbivores } \\
\hline 0 & 579 & 226 & 88 & 1.04 & $8.72^{2}$ & 0.92 \\
\hline 15 & 377 & 142 & 176 & & & \\
\hline 20 & 1198 & 433 & 56 & & & \\
\hline 35 & 1202 & 162 & 100 & & & \\
\hline \multicolumn{7}{|c|}{ Omnivores } \\
\hline 0 & 1.5 & 1.0 & 4.0 & 0.15 & 1.75 & 0.84 \\
\hline 15 & 3.5 & 1.0 & 6.5 & & & \\
\hline 20 & 7.5 & 1.0 & 0 & & & \\
\hline 35 & 5.5 & 0.5 & 2.5 & & & \\
\hline \multicolumn{7}{|l|}{ Predators } \\
\hline 0 & 1.5 & 0 & 0.5 & 1.93 & $10.32^{2}$ & 1.89 \\
\hline 15 & 6.0 & 0.5 & 2.0 & & & \\
\hline 20 & 4.0 & 0.5 & 0 & & & \\
\hline 35 & 2.5 & 0 & 3.5 & & & \\
\hline \multicolumn{7}{|c|}{ Total nematodes } \\
\hline 0 & 1267 & 642 & 405 & 1.18 & $16.17^{2}$ & 2.70 \\
\hline 15 & 1004 & 411 & 2142 & & & \\
\hline 20 & 1640 & 650 & 332 & & & \\
\hline 35 & 1851 & 342 & 429 & & & \\
\hline
\end{tabular}

${ }^{1} F$ values from analysis of variance (ANOVA) significant at $P<0.01$.

${ }^{2} F$ values from analysis of variance (ANOVA) significant at $P<0.05$.

years, total nematodes recovered from the summer pastures averaged $1346 \cdot 100 \mathrm{~cm}^{-3}$ soil at the zero cow-calf pair density and $1367 \cdot 100 \mathrm{~cm}^{-3}$ soil at the 35 cow-calf pair density (Table 1). Annual differences were apparent, with more fungivores present in 1999 than in the other years $(P \leq 0.01)$ and fewer bacterivores present in the final year (2002) than in earlier years $(P \leq 0.05)$. Stocking density did not affect $(P>0.10)$ nematode numbers in grazed winter pastures (Table 2 ). In winter pastures, total nematodes recovered averaged $771 \cdot 100 \mathrm{~cm}^{-3}$ of soil at the zero rate and $874 \cdot 100 \mathrm{~cm}^{-3}$ at the $35 \mathrm{cow}-$ calf rate. An interaction between stocking density and time was due to unusually high levels of bacterivores in the 15 cow-calf rate in 2003 (Table 2). Although soil moisture data were not consistently collected during this experiment, available data indicated that soil moisture in winter pastures averaged $23.9 \%$ on 15 April 1999 and $12.2 \%$ on 6 June 2002. Total nematode
Table 3. Effect of stocking density on nematode richness (genera per sample) over time, in summer/tame and winter/native pastures at end of grazing cycle.

\begin{tabular}{|c|c|c|c|c|c|c|}
\hline \multirow[b]{2}{*}{$\begin{array}{l}\text { Cow-calf } \\
\text { pairs per } \\
\text { pasture }\end{array}$} & \multicolumn{3}{|c|}{ Summer pastures } & \multicolumn{3}{|c|}{ Winter pastures } \\
\hline & $\begin{array}{c}23 \\
\text { November } \\
1999\end{array}$ & $\begin{array}{c}30 \\
\text { October } \\
2001\end{array}$ & $\begin{array}{c}19 \\
\text { November } \\
2002\end{array}$ & $\begin{array}{c}15 \\
\text { April } \\
1999\end{array}$ & $\begin{array}{c}6 \\
\text { June } \\
2002\end{array}$ & $\begin{array}{c}3 \\
\text { June } \\
2003\end{array}$ \\
\hline 0 & 31.0 & 29.5 & 28.0 & 20.5 & 19.0 & 26.5 \\
\hline 15 & 29.5 & 23.0 & 23.0 & 22.0 & 16.5 & 27.0 \\
\hline 20 & 36.0 & 27.0 & 27.5 & 22.5 & 20.5 & 18.0 \\
\hline 35 & 28.0 & 25.5 & 29.5 & 27.5 & 16.0 & 24.5 \\
\hline \multicolumn{7}{|l|}{ ANOVA $F$ values } \\
\hline Density & & 2.64 & & & 0.49 & \\
\hline Time & & $4.85^{1}$ & & & $9.51^{2}$ & \\
\hline Density $\times$ time & & 1.08 & & & 3.17 & \\
\hline
\end{tabular}

${ }^{1} F$ values from analysis of variance (ANOVA) significant at $P<0.05$.

${ }^{2} F$ values from analysis of variance (ANOVA) significant at $P<0.01$.

numbers on these dates averaged $1440 \cdot 100 \mathrm{~cm}^{-3}$ soil and $511 \cdot 100 \mathrm{~cm}^{-3}$ soil, respectively (Table 2 ).

Soil samples contained a rich biodiversity of nematodes, averaging 28.1 genera per sample in summer pastures and 21.7 genera per sample in winter pastures (Table 3). Richness (number of genera per sample) was not affected $(P>0.10)$ by cattle density treatments (Table 3). However, greater richness was observed in summer pastures in 1999 (31.1 genera per sample) than in 2001 (26.2 genera) or 2002 (27.0 genera). In winter pastures, richness averaged 23.1 genera per sample in 1999, declined to 18.0 genera per sample in 2002, and recovered to 24.0 genera per sample in 2003 (Table 3). Richness data showed a similar trend to abundance data in that no differences due to grazing were observed following 6 grazing cycles ( 2 pasture types $\times 3$ years).

\section{DISCUSSION}

Grazing studies often focus on forage parameters (e.g., production, utilization, nutritive quality), surface water parameters (e.g., infiltration, runoff, chemical composition), or consumer parameters (e.g., cattle weight gains, calving percentages, animal condition scores). We were interested in determining if a range of cattle stocking rates would influence a common and ubiquitous biological constituent of the pasture ecosystems. Nematodes were not affected significantly by the grazing treatments imposed in the current study; however, they appeared to be influenced by more limiting ecological factors.

The high proportion of herbivores at this site is consistent with results from other pasture sites, which provide abundant resources to root-feeding nematodes (McSorley 1997a, 1998). Herbivores, predators, and total nematodes were more abundant in 1999 than in other years $(P<0.01)$. It is well known that nematodes are strongly influenced by seasonal trends in environmental factors, particularly soil moisture (McSorley 1997a, 1997b; McSorley and Frederick 2000). The year 2000 was unusually dry at these sites, and the data suggest that nematode numbers decreased following this drought and had not recovered to 1999 levels in some instances. Although 
limited, soil moisture data from the current study are consistent with correlations between nematodes and soil moisture observed in a previous study (McSorley 1997b). Annual trends in soil moisture from year to year have had similar effects on nematodes in other studies as well (McSorley 1997a; McSorley and Frederick 2000).

Although nematode bacterivores and fungivores are known to be affected differentially by grazing in some instances (Wardle et al. 2004), neither group was affected by grazing here, but seasonal trends were similar for both trophic groups. Heterogeneity within soil ecosystems is well known (Augustine and Frank 2001; Bardgett and Wardle 2003), and as a result nematode sampling data may be quite variable. Because the sampling plan used here was sufficient to detect seasonal differences consistently, it would seem that grazing effects, if any, should be detected as well. However, the stocking densities used, which were typical of production practices in southcentral Florida, did not result in pastures grazed homogeneously. Even at the highest cattle density, patches of ungrazed or lightly grazed grass remained. Thus it is possible that belowground responses may have occurred at very small local scales because of grazing, but these did not translate into differences at the scale of the plots sampled because we composited soil cores over a $10 \times 10 \mathrm{~m}$ area. This scenario is possible if nematode patches are very small $(<1 \mathrm{~m}$ across $)$, but becomes less likely if nematode patches are large, particularly if patches are larger than the plot size used.

It has been known for some time that the extreme clumping and patchiness of nematodes in soil makes it difficult to sample areas $>1$ ha reliably (McSorley 1987). On the other hand, sampling a small plot $\left(100 \mathrm{~m}^{2}\right)$ avoided the patchiness and normalized nematode distribution data (Proctor and Marks 1975). More recent work has provided insight into the size of spatial patches occupied by nematodes, which can range up to 67-80 $\mathrm{m}$ across (Ettema and Wardle 2002). Robertson and Freckman (1995) found patch sizes ranging from 6 to $80 \mathrm{~m}$, with an average of $35 \mathrm{~m}$ across, although they sampled a very large (48-ha) area for their study site. In more moderate study sites ( $<1 \mathrm{ha}$ ), patch sizes were generally $13-16 \mathrm{~m}$ (Liang et al. $2003,2005)$. The plot size used in our study, $10 \times 10 \mathrm{~m}$, seems to be smaller than the average patch sizes reported in these recent studies of patch size, which should minimize the variability due to patchiness within the sampling site.

Sampling within the plot size used detected seasonal effects on nematode population levels, but no impact from stocking rate was observed. Grazing was shown to impact nematode communities in many studies, but in other cases, no impact was observed, or results depended on environmental conditions (Bardgett et al. 1997, 1998). Heavy grazing appears to have a consistent impact on nematode communities (Ingham and Detling 1984). An overview of many sites with various levels of grazing in the Netherlands confirms that nematode abundance was reduced in the most heavily grazed sites (Mulder et al. 2003). In this context, it may be that the grass in our site was not grazed heavily enough to result in impact on nematode communities. Grass in the plots remained healthy under relatively light grazing pressure, and recovered and grew vigorously in the subtropical climate of the region. The highest experimental treatment used (35 cow-calf pairs per pasture) is substantially greater than the stocking rates of $15-20$ cow-calf pairs per pasture that are typically used in south-central Florida. Results are encouraging in that typical stocking rates used in south-central Florida did not result in nontarget effects on the soil nematode community, at least at the levels of scale examined here.

\section{MANAGEMENT IMPLICATIONS}

Nontarget effects can potentially occur in any ecosystem as a result of management practices. Nematodes are often used as bioindicators of nontarget effects in soil ecosystems due to their widespread distribution, diversity, and involvement in nutrient cycling (Bongers and Bongers 1998). However, increasing cattle stocking rates to nearly twice the densities typically used in south Florida had no effect on nematodes in the grazed pastures. Therefore, managers in this Florida system do not appear to risk nontarget impacts on the nematodes involved in nutrient cycling if stocking rates are changed or even increased. In some temperate studies, however, moderate to high levels of grazing have adversely affected nematode abundance (Bardgett and Wardle, 2003; Mulder et al. 2003). Our results suggest that the impact of grazing may vary in subtropical and temperate pastures, possibly a result of the cattle densities used or the ability of grasses to recover more quickly in subtropical systems.

\section{LITERATURE CITED}

Anderson, A. N. 1999. My bioindicator or yours? Making the selection. Journal of Insect Conservation 3:61-64.

Augustine, D. J., AND D. A. Frank. 2001. Effects of migratory ungulates on spatial heterogeneity of soil nitrogen properties on a grassland ecosystem. Ecology 82:3149-3162.

Bardgett, R. D., D. K. Leemans, R. Cook, and P. J. Hobbs. 1997. Seasonality in the soil biota of grazed and ungrazed hill grasslands. Soil Biology and Biochemistry 29:1285-1294.

Bardgett, R. D., And D. A. Wardle. 2003. Herbivore mediated linkages between aboveground and belowground communities. Ecology 84:2258-2268.

Bardgett, R. D., D. A. Wardle, and G. W. Yeates. 1998. Linking above-ground and below-ground interactions: How plant responses to foliar herbivory influence soil organisms. Soil Biology and Biochemistry 30:1867-1878.

Begon, M., J. L. Harper, and C. R. Townsend. 1990. Ecology: Individuals, populations and communities. 2nd ed. Boston, MA: Blackwell Scientific Publications. 945 p.

Bolen, E. G., AND W. L. RoBinson. 1999. Wildlife ecology and management. 4th ed. Upper Saddle River, NJ: Prentice Hall. 605 p.

Bongers, T., AND M. Bongers. 1998. Functional diversity of nematodes. Applied Soil Ecology 10:239-251.

Coleman, D. C., and D. A. Crossley, JR. 1996. Fundamentals of soil ecology. San Diego, CA: Academic Press. 205 p.

Ettema, C. H., and D. A. Wardle. 2002. Spatial soil ecology. Trends in Ecology and Evolution 17:177-183.

Ferris, H., T. Bongers, and R. G. M. dE Goede. 2001. A framework for soil food web diagnostics: Extension of the nematode faunal analysis concept. Applied Soil Ecology 18:13-29.

Ferris, H., R. C. Venette, and K. M. Scow. 2004. Soil management to enhance bacterivore and fungivore nematode populations and their nitrogen mineralization function. Applied Soil Ecology 25:19-35.

Fiscus, D. A., AND D. A. Neher. 2002. Distinguishing sensitivity of free-living soil nematode genera to physical and chemical disturbances. Ecological Applications 12:565-575.

Ingham, R. E., And J. K. DetLing. 1984. Plant-herbivore interactions in a North America mixed-grass prairie. III. Soil nematode populations and root biomass 
on Cynomys ludovicianus colonies and adjacent uncolonized areas. Oecologia 63:307-313.

JenkINS, W. R. 1964. A rapid centrifugal-flotation technique for separating nematodes from soil. Plant Disease Reporter 48:692.

Liang, W., Y. Jiang, Q. LI, Y. LIU, And D. Wen. 2005. Spatial distribution of bacterivorous nematodes in a Chinese Ecosystem Research Network (CERN) site. Ecological Research 20:481-486.

Liang, W., Q. LI, Y. Jiang, W. B. Chen, and D. Wen. 2003. Effect of cultivation on spatial distribution of nematode trophic groups in black soil. Pedosphere 13:97-102.

MCSORLEY, R. 1987. Extraction of nematodes and sampling methods. In: R. H. Brown and B. R. Kerry (EDS.) Principles and practice of nematode control in crops. Sydney, Australia: Academic Press. p 13-47.

McSoRLEY, R. 1997a. Relationship of crop and rainfall to soil nematode community structure in perennial agroecosystems. Applied Soil Ecology 6:147-159.

McSorley, R. 1997b. Correlation of nematode densities and rainfall in a Florida pasture. Soil and Crop Science Society of Florida Proceedings 56:55-57.

McSorley, R. 1998. Nematode communities in managed pastures in north Florida. In: R. G. M. de Goede and T. Bongers (EDS.) Nematode communities of northern temperate grassland ecosystems. Giessen, Germany: Focus Verlag. p 319-320.

McSorley, R., ANd J. J. Frederick. 1999. Nematode population fluctuations during decomposition of specific organic amendments. Journal of Nematology 31:37-44.

McSorley, R., and J. J. Frederick. 2000. Short-term effects of cattle grazing on nematode communities in Florida pastures. Nematropica 30:211-221.

Mulder, C. H., D. de Zwart, H. J. van Wijnen, A. J. Schouten, and A. M. Breure. 2003. Observational and simulated evidence of ecological shifts within the soil nematode community of agroecosystems under conventional and organic farming. Functional Ecology 17:516-525.

Proctor, J. F., and C. J. Marks. 1975. The determination of normalizing transformations for nematode count data from soil samples and of efficient sampling schemes. Nematologica 20:395-406.

Robertson, G. P., and D. W. Freckman. 1995. The spatial distribution of nematodes across a cultivated ecosystem. Ecology 76:1425-1432.

StILING, P. 2002. Ecology: Theories and applications. 4th ed. Upper Saddle River, NJ: Prentice Hall. $403 p$.

Swain, H. M., P. J. Bohlen, K. L. Campbell, L. O. Lollis, and A. D. Steinman. 2007. Integrated ecological and economic analysis of ranch management systems: an example from South Central Florida. Rangeland Ecology and Management 60:1-11.

Wang, K. H., R. McSorley, and R. N. Gallaher. 2004a. Effect of winter cover crops on nematode population levels in north Florida. Journal of Nematology 36:517-523.

Wang, K. H., R. McSorley, and R. N. Gallaher. 2004b. Relationships of nematode communities and soil nutrients in cultivated soils. Soil and Crop Science Society of Florida Proceedings 63:105-113.

Wang, K. H., R. McSorley, A. J. Marshall, and R. N. Gallaher. 2004c. Nematode community changes associated with decomposition of Crotalaria juncea amendment in litterbags. Applied Soil Ecology 27:31-45.

Wardle, D. A., R. D. Bardgett, J. N. Klironomos, H. Setala, W. H. van der Putten, and D. H. WALL. 2004. Ecological linkages between aboveground and belowground biota. Science 304:1629-1633.

Yeates, G. W., R. G. M. de Goede, D. W. Freckman, and S. Georgieva. 1993. Feeding habits in soil nematode families and genera-An outline for soil ecologists. Journal of Nematology 24:315-331. 